\title{
Muş Bölgesi Aşiretlerinin İç Çelişkileri Çerçevesinde Yerel ve Merkezi İktidarla Diyalektik ve Dikotomik İlişkisi*
}

\section{Dialectical and Dichotomic Relationship with Local and Central Power in the Framework of Internal Contradictions of the Tribes of Muş Region}

Orhan Örs a,***

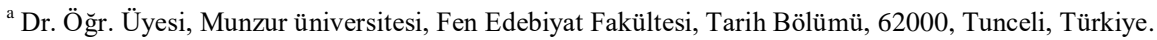
ORCID: 0000-0003-4184-9775

\begin{tabular}{l} 
MAKALE BİLGİSİ \\
\hline Makale Geçmişi: \\
Başvuru Tarihi: 26 Kasım 2020 \\
Düzeltme Tarihi: 14 Aralık 2020 \\
Kabul Tarihi: 17 Aralık 2020 \\
\hline Anahtar Kelimeler: \\
Osmanlı \\
Muş \\
İktidar \\
Aşiret \\
Aşiretçilik
\end{tabular}

\section{A R T ICLE IN F O}

\section{Article history:}

Received 26 November 2020

Received in revised form 14 December 2020

Accepted 17 December 2020
ÖZ

Bu çalışmada, Osmanlı ve Fransız arşiv belgeleri esas alınarak Muş bölgesinde mukim bulunan aşiretler arası gerilimler ile aşiretlerin Osmanlı merkezi iktidarıyla geliştirdiği ilişkiler değerlendirilecektir. Osmanlı'nın son dönemine yoğunlaşacak olan çalışma, bu dönemde Muş ve çevresinde yaşayan halkın sosyo-ekonomik, sosyo-kültürel ve sosyo-politik durumlarını mercek altına almaya çalışacaktır.

\section{Keywords:}

Ottoman

Muş

Power

Tribe

Tribalism

\section{A B S T R A C T}

In this study, based on Ottoman and French archival documents, tensions between tribes and the relations developed by tribes with the Ottoman central government will be evaluated. The study, which will focus on the last period of the Ottoman Empire, will try to examine the socio-economic, socio-cultural and socio-political situations of the people living in Muş and its surroundings.

\section{Giriş}

Bu çalışmada, Muş bölgesi aşiretlerinin merkezi iktidar ve yerel iktidarla geliştirdiği diyalektik ${ }^{1}$ ve dikotomik $^{2}$ ilişkiler

\footnotetext{
1 "Gerçekliği ve onun çelişmelerini incelemeye yarayan ve bu çelişmeleri aşmayı sağlayan yolları aramayı öngören akıl yürütme yöntemi” (https://sozluk.gov.tr/).
}

üzerinde durulacak, bölgede yerleşik aşiretlerle haymenişin (göçebe) aşiretlerin ilişkisi değerlendirilecektir. Aşiretler, bir taraftan Osmanlı merkezi iktidarıyla geliștirdikleri ilişkiler çerçevesinde yönünü belirlerken diğer taraftan

\footnotetext{
2 “İkileşim", genellikle birbiriyle çelișkili kısımlar, kategoriler veya fikirler olmak üzere, ikiye bölünme (https://www.seslisozluk.net/dikotomi-nedir-ne-demek/).
}

* Bu çalışma, 22-23 Ekim 2020 tarihlerinde Muş Alparslan Üniversitesinde düzenlenen II. Uluslararası Muş Sempozyumunda sözlü bildiri olarak sunulmuştur.

** Sorumlu yazar/Corresponding author.

e-posta: orhanors@munzur.edu.tr 
bölgenin yerel iktidarı ve diğer aşiretlerle geliştirdikleri ilişkiler bağlamında bir yaşam biçimi inşa etmişler. Dolayısıyla, çalışmada bölgenin hakim toplumsal örüntüsü olarak öne çıkan aşiret yapısının sosyo-ekonomik, sosyopolitik ve sosyo-kültürel doku üzerindeki etkisi literatürde var olan bazı kuramlar çerçevesinde analitik bir perspektifle ele alınacaktır. Ayrıca, bu örüntünün yol açtığı sorunlar ile ürettiği sonuçların bölgenin sonraki dönemleri üzerindeki etkilerine de değinilecektir. Bundan ötürü de çalışmaya kuramsal bir çerçeve oluşturarak başlamak gerekmektedir.

Charles Tilly, devlet ${ }^{3}$ denilen olguyu değerlendirirken "dolayll" ve "doğrudan yönetim" kavramlarını geliştirmiştir. Dolaylı yönetim; devletlerin yerel aracıları ve kurumları vasıta kılarak tebaasının gündelik hayatına müdahalesini en alt düzeyde tutması anlamina gelmektedir. $\mathrm{Bu}$ yönetim anlayışını benimseyen devletler, bireylere tek tek nüfuz etmek veya onların bağlılığını kazanmak yerine, yerelin güçlü aracıları vasıtasıyla kurduğu ittifaklar yoluyla yerel halkın üzerinde tahakküm kurmayı tercih etmektedir. Yerel iktidar sahipleriyle kurduğu bu ittifaklar sayesinde devlet, bir yandan yerelden merkeze süreklilik arz eden kaynak akışı sağlamakta diğer yandan yerelin gündelik yaşam pratiklerine minimum düzeyde karışmaktadır. Ancak bu yönetim anlayışı zamanla değişiklik arz etmiştir. Çünkü devletler zaman içinde savaşlar yüzünden kaynaklarını sürekli artırmak durumunda kalmaktadır. Kaynak ihtiyacı artan devletler de ittifak kurdukları yerel araciları devreden çıkarmak ve dolaylı yönetimlerde önemli bir kısmı yerel beylere bırakılan mali kaynağın tümünün doğrudan merkeze aktarılmasını sağlama yoluna gitmektedir. Esasında devlet, bu anlayışla yerelde doğrudan tahakküm kurmaya da çalışmaktadır. Bu anlayışla doğrudan yönetimi inşa etmeye çalışan devlet, merkezi yönetimi güçlendirecek yeni araçlara kavuşmaktadır. Tilly, doğrudan yönetim anlayışını tercih etmeye başlayan modern devletlerin vergilendirme, nüfus sayımı, genel askerlik, polis sistemi gibi aygıtları işlevsel kılarak toplumsal yaşamın mikro alanlarına girdiklerini ve onların denetiminde bulunan kaynaklara ulaşma olanağı elde ettiklerini ifade etmektedir (Tilly, 2001; Yılmaz, 2014: 11). İbn Haldun meseleye farklı bir pencereden bakmakta, devletlerin tercih ettikleri yönetim anlayışının sebeplerini başka etkenlerle açıklamaktadır. Haldun'a göre geleneksel devlet/toplumlarda iktidarı ellerinde bulunduranlar merkezlerde daha güçlü iken periferileriyle sınır boylarında daha zayıf bir durumda olurlar. Bu devletler topraklarını iyice genişletip tabi sınırlarına ulaştığı zaman artık fazla

\footnotetext{
3 Weber, devlet denilen olgunun temel işlevlerinin bulunduğunu ve bunların da: "yasaların çıkarılması (yasama işlevi); kişisel güvenliğin ve kamu düzeninin korunması (güvenlik); kazanılmış hakların korunması (adalet yönetimi); sağlıksal, eğitimsel sosyal refahın ve diğer kültürel gereksinimlerin sağlanması (çeşitli yönetim alanlart ve sonucu) ve çok önemli olarak dişarıdan gelen saldırıya karşı düzenli silahl koruma (askeri idare)" olduğunu dile getirmektedir (Weber, 2012: 271). Ergut, Batılı toplumlarda meşru güç kullanımına malik devletlerin vücut bulmasının ekonomik ve sosyal değişimlerin birlikte yol almasıyla gerçekleşebildiğini, fakat Batılı olmayan toplumlarda modern bürokratik devletlerin kapitalist iktisadi örgütlenmesiyle tanışmadan önce neşvünema bulduklarını dile getirmektedir (Ergut, 2015: 43).
}

ileriye gidemezler. Haldun, bu durumu şöyle bir metaforla açıklamaktadır: "Tıpkı belli merkezlerden çıkan ışığın ve aydınlığın çevreye yayıldıkça zayıflamasında ve içine taş atıldı̆̆ zaman gittikçe genişleyen su yüzeyindeki dairlerde olduğu gibi." Bu tür devletlerde merkez yenilgiye uğratıldiğında çevrede kendiliğinde ortadan kalkar. Başka bir ifadeyle merkezin yenilmesi devletin dă̆lmasi anlamına gelir. Çünkü bu tür yapılarda "merkez, kendisinden ruhun ve canın çevreye yayıldığ kalp gibidir. Kalp mağlup edilir ve ona malik olunursa. Bütün çevre ve uç noktalar hezimete uğrar" (Haldun, 2016: 383).

Geleneksel devlet/toplumlarda merkezin idari kapsamı, gücünün yoğunlaştığı merkezlerden uzamsal olarak uzak olan bölgelerde yerel halkın uygulamalarını kapsayacak kadar genişleme şansına sahip olamamıştır. Bu yapılarda merkezi iktidarın şiddet aygıtları üzerindeki göreceli düşük hakimiyeti modern anlamda "polislik" imkânının yeterli düzeyde olmadığını, merkezi iktidara karşı askeri türden potansiyel meydan okuma kaynaklarının yerelde bulunduğu göstermektedir (Giddens, 2008: 241). Farklı kavram setlerini kullanarak meseleye yaklaşsa da Giddens da Tilly gibi geleneksel devlet yapılanmasının tipik örneklerinden olan imparatorlukların, topraklarına kattıkları yeni bölgelerin yerli halklarının, vergilerini ödemeleri veya istenen haraçları vermeleri koşuluyla, davranış biçimlerini sürdürmelerine ses çıkarmadıkları gibi onları bu noktada serbest bıraktıkları dile getirmektedir (Giddens, 2008: 75). $\mathrm{Bu}$ ilişki biçiminin Osmanlı'nın Kürt coğrafyasını topraklarına kattıktan sonra Kürt mirleriyle geliştirdiği ilişkide hakim olduğu görülmektedir. Aşağıda yeri geldiğinde detaylı bir şekilde anlatılacak olan Osmanlı-Kürt mirleri ilişkisi yaklaşık üz yüzyıl boyunca dolaylı yönetim anlayışının hakim olduğu bir model çerçevesinde yürütülmüştür. Bölgeyi hakimiyeti altına aldıktan sonra Osmanlı merkezi iktidarı, Kürt mirlerini aracı kılmış, bu mirler vasıtasıyla bölgeyi yönetmeyi tercih etmiştir.

Tilly, yerel iktidar sahibi soylularla köylülerin aynı dini, dili ve gelenekleri paylaşmalarının, merkezi iktidarın işini kolaylaştırdığını, bu tür durumlarda bulunan bölge halklarının merkezin isteklerine karşı daha duyarlı olduklarını fakat yöneticilerin yabancı olduğu, merkezi iktidar tarafından dışarıdan atanan yerel iktidar sahipleri, tarihin çoğunda Avrupa'nın Osmanlı İmparatorluğu topraklarında yaşandığı gibi bölgelerde halkla merkez arasında bağlantıyı ancak köy kocabaşları ile aşiret reislerin kurabildiğini ifade etmektedir. $\mathrm{Bu}$ bölgelerin derebeyleri, merkezi iktidarın gücü zayıfladığında yerelde bütün kontrolü ele geçirebilmektedirler. Osmanlı da bu durumu özellikle 19. yüzyılda deneyimlemiştir (Tilly, 2001: 185). Bu çerçevede mesele değerlendirildiğinde Osmanlı'nın aynı dili olmasa da aynı inancı paylaştığı Kürt bölgesiyle daha sağlam ilişkiler kurduğu özellikle 19. yüzyılda anlaşılmış, milliyetçilik çağı olarak da değerlendirilen bu dönemde, Hıristiyan halklar milliyetçi taleplerle mücadeleye girişirken, diğer Müslüman halklar gibi Kürtler de Osmanlı'nın karşısına milli taleplerle çıkmamıştır. Ancak Osmanlı'nın yerel Kürt aristokrasisiyle kurduğu geleneksel ilişki, devletin 18. yüzyılın sonlarından itibaren başlattığı modernleşme hamleleriyle değişmeye başlamış, Kürt mirleriyle kurulan ikili yapı bozulmuş, çelişkilerin arttığı ve çatışmaların yoğunlaştığı yeni bir dönem başlamıştır. 
Anthony Giddens da geleneksel devletlerin/toplumların esas itibariyle karakterde parçalı olduklarını, siyasal merkezlerinin idari menzillerinin oldukça düşük olduğunu, dolayısıyla da modern anlamda "yönet"mediklerini dile getirmektedir. $\mathrm{Bu}$ tür yapıların sinırları yoktur, sadece hudut bölgeleri bulunmaktadır (Giddens, 2008: 11). Geleneksel devlet/toplumdan modern devlet/topluma geçmenin göstergeleri olarak "haraçtan vergiye, dolaylı yönetimden doğrudan yönetime, baş ĕgdirmeden özümlemeye geçiş süreci” şeklinde olgular yaşanmaktadır. $\mathrm{Bu}$ süreçte devletler çoğunlukla yönettikleri halkı tek biçimli kılmaya çalışmakta; tebaalarıyla ticaret, ulaşım ve iletişim araçları vasıtasıyla yeni bağlar kurmanın yollarını aramakta; ortak dil, din, para ve hukuk düzeni dayatarak farklılıkları/bölünmüşlükleri ortadan kaldırarak homojen bir toplum inşa etmek için çalışmaktadırlar. Ancak bu tekdüzeleşme, yönetilen halkların toplumsal ilişkilerini şekillendiren kimliklerini tehdit eder duruma geldiğinde, genellikle, kitlesel bir direnişle karşılaşmaktadır (Tilly, 2001: 176-177). Başka bir ifadeyle geleneksel devlet/toplumlarda, merkezi iktidarın kontrolünde bulunan askeri kuvvetlerin gücünden bağımsız olarak, merkezin denetiminden kaçabilen silahlı muhalefet kaynakları bulunmaktadır. $\mathrm{Bu}$ tür devlet/toplumlar parçalı karakterlerinin bir ifadesi olarak güçlü savaşçı yerel beyler, yağmacı göçebe gruplar ile her türden eşkıya topluluklarını barındırırlar bünyelerinde (Giddens, 2008: 27-28). Çalışmanın ileri safhalarında görüleceği gibi Osmanlı-Kürt mirlerinin ilişkisi özellikle de II. Mahmut'un iktidarında farklı bir boyut kazanacak, modernleşmeye/merkezileşmeye çalışan Osmanlı, Kürt mirlerini devreden çıkarmaya çalışacak, bu mirlerle karşı karşıya gelirken zorlanacak ancak en sonunda amacına ulaşacaktır. Bu çerçevede, Osmanlı merkezi iktidarıyla periferide inşa edilen yerel Kürt iktidarı arasındaki ilişkinin, şartların da belirleyiciliği altında, kimi zaman çatışmalı (diyalektik) kimi zaman da birbirini tamamlayan ikili (dikotomik) bir şekil aldığı görülecektir.

\section{Aşiret, Aşiretçilik ve Asabiyet (Kavmiyetçilik)}

Çalışmanın bu kısmında, Muş bölgesinin hakim toplumsal örüntüsü olarak görülen aşiret, aşiretçilik, kabilecilik; asabiyet (kavmiyetçilik) patrimonyalizm ve patriyarkalizm gibi kavramlardan destek alınarak analiz edilmeye çalışılacak, Kürt coğrafyasının öne çıkan niteliği olan bu olgusal ve düşünsel yapıların, bölge aşiretlerinin tutum ve davranışlarını ne düzeyde açıkladığına bakılacaktır. Bu bağlamda mesele ele alındığında İbn Haldun, geleneksel toplumlarda birlikte mücadele edip, diğerlerine karşı koymanın yalnızca asabiyetle (akrabalık) mümkün olduğunu, yardıma koşmayı savaşlarda cesaretle çarpışmayı bu düşüncenin sağladığını, asabiyet kapsamında olan herkesin diğerleri için gönüllü olarak canını feda ettiklerini dile getirmektedir. Bu toplumsal örüntüye sahip olan halklarda asabiyet her şeyden; maldan, mülkten, arzu ve isteklerden daha üstün bir mevki olarak telakki edilmektedir. Dolayısıyla da asabiyet düşüncesiyle yoğrulmuş olan halklar, savaşmadan topraklarını asla başkalarına bırakmazlar. Bu yüzden asabiyet duygusunun yoğun olduğu topraklarda çekişme ve mücadele doğal bir durum haline gelmekte ve bu da savaşlara ve çatışmalara sebep olmaktadır. Haldun, eğer asabiyet olmasa bu durumlardan hiçbirinin yaşanmayacağını da iddia etmektedir (Haldun, 2016: 373). İbn Haldun, asabiyet kavramı üzerinde dururken, akrabalık bağının tabi bir durum olduğunu, akrabalık ilişkisi olanların birbirlerine bağlı olduklarını ve "zarar uğrayan veya mahvolma durumunda kalan" akrabalara yardıma koşmanın bir zorunluluk olarak telakki edildiğini ifade etmektedir. Bu toplumsal örüntüde insanların, zulme veya tecavüze uğrayan akrabaları olduğunda kendilerini zelil hissettiklerini, bunu telafi etmenin yollarını aradıklarını dile getirmektedir. Haldun'a göre bu anlayış insanlığın ilk gününden itibaren var olmuş, tabii bir durumdur. $\mathrm{Bu}$ toplumlarda birbirine yardıma koşma, insanlar arasındaki akrabalık bağıyla yakından ilintilidir (Haldun, 2016: 334335). Albert Hourani ise aşiret kavramının iki tür toplumsal varlığı tanımlamak için kullanılabileceğini, bunlardan ilkinin, "sı̆̆ır yetiştiren çoban birimlerinin veya köylerinin özel bir amaca yönelik kooperatif birlikleri gibi hayvan yetiştiren veya tarımla uğraşan, doğal bir kırsal toplum olgusu olarak karşımıza" çıktığını ifade etmektedir. Bu yap1 hayvancılıkla uğraşan, ekim ve hasat işlerinde, toprağın belli sürelerle yeniden dağıtımında ve kimi zamanda ötekilere karşı birbirlerini savunma gibi zorunluluklardan dolayı birbirlerine sarılmaktadırlar. Hourani, ikincisinin ise aşiret kavramının sadece grup dayanışması şeklindeki özellikler göz önüne alınarak tanımlanabilen daha geniş topluluklara işaret ettiğini, bu toplumsal örüntüde yer alan aşiret olgusunun daha geniş ve büyük gruplarında, bir "mit”'in etrafinda oluşan ortak soyun, akrabalığın yerine geçtiğini ifade etmektedir (Hourani, 1990: 304 ; Örs, 2019: 56).

Geleneksel devlet/toplumlarda "vahşi”" kavimler/aşiretler diğerlerinden, bedeviliklerinin bir gereği olarak, daha cesur olmak zorundadırlar. Geleneksel yapilarda "daha cesur" olanlar, diğer halklar üzerinde hakimiyet kurma olanağına sahip olur ve onların "elinde ve avucunda olan şeyleri" alırlar. $\mathrm{Bu}$ tür toplumsal yapılar, ovalara inip yerleşik hayata geçtikleri nispette değişime uğrarlar. Maddi imkanların bollaştı̆ğ bu yeni durumda "vahşi " kavimlerin bedevilikleri azalmaya yüz tutar ve şecaatleri ile cesaretleri de azalır (Haldun, 2016: 348-349). Haldun, vahşi toplumların daha geniş topraklara sahip olduklarını çünkü bu tür halkların diğerleri üzerinde hegemonya kurmaya daha yatkın olduklarını, savaş yapma kabiliyetlerinden dolayı diğer kavimleri boyunduruk altına almaktan geri durmadıkları dile getirmektedir. Haldun, bu tür halkların durumunu şu şekilde ortaya koymaktadır: "Bir sebep de şudur: Vahşi ve yabani hayvanların ehlileşmiş hayvanlar karşısındaki durumu gibidir. Bunlar Arap, Zenate ve onlar hükmünde olan Kürtler, Türkmenler ve Sinhace'den gibi kavimlerdir" (Haldun, 2016: 348-349).

İçinde yaşadığı dönemin sosyolojisini de göz önünde bulunduran İbn Haldun, dönemin İslam coğrafyasında hakim toplumsal örüntü olarak öne çıkan aşiret yapısını ve kavimlerin içinde bulunduğu sosyo-ekonomik, sosyokültürel ve sosyo-politik durumu da ortaya koymakta, geliştirdiği kavramlarla geleneksel toplumu tahlil etmektedir. Haldun, intikama dayanan ve mukatele (karşılıklı birbirini katletme) şeklinde yaşanan olayların çoğunlukla komşu kabile ve kavimler arasında vuku bulduğunu, aralarında rekabet bulunan aşiretlerin bu tür çatışmalara girmeye her an hazır olduklarını ifade etmektedir. Düşmanlığa dayanan çatışmalar ise çoğunlukla Araplar, Türkler, Kürtler gibi dağlarda ve çöllerde yaşayan vahşi halklarda görülmektedir. Haldun, bu kavimlerin 
geçimlerini mızraklarıyla sağladıklarını, maişet kaynaklarının başkalarından elde ettikleri ganimetlerden oluştuğunu dile getirmektedir. $\mathrm{Bu}$ kavimler "geçim kaynaklarını" vermeye yanaşmayanlara karşı savaş ilan etmekten geri durmazlar. Yağmaya/talana dayalı bir ekosistem kuran bu halkların rütbe veya mülk gibi bir dertleri bulunmamaktadır. İstedikleri ve elde etmeye çalıştıkları tek şey "insanların elinden ve avucundan bulunan şeyleri" zor aygıtını işlevsel kılarak, kendi geçimleri için almaktır (Haldun, 2016: 358-359).

Aşiret, kabile, etnisite, aşiretçilik ve kabilecilik gibi olguları farklı boyutlarıyla değerlendiren Max Weber, grup hısımlığının (yakınlık) nesnel yakınlık koşullarına bağlı olmaksızın, özellikle siyasi bir topluluğun kurulması için önemli sonuçlar doğurabildiğini dile getirmektedir. Bu tür yapıları etnik gruplar olarak tanımlayan Weber, bu toplumsal örüntüde fiziksel tipin, geleneklerin veya her ikisinin benzerliğinin ya da kolonizasyon ve göç anıları yoluyla ortak soya olan ortak inancin belirleyici olduğunu ifade etmektedir. $\mathrm{Bu}$ inancı bir zorunluluk olarak değerlendiren Weber, nesnel bir kan bağı olup olmamasının ise önemli olmadığını belirtmektedir. Yazar, etnik üyeliğin grup oluşumunda değil, siyasi anlamda grup oluşumunu kolaylaştırdığına inanmaktadır. Bundan dolayı da esas olan "ortak etnisiteye inancl esinleyen, ne kadar yapay olarak örgütlenmiş olursa olsun öncelikle siyasi topluluktur" (Weber, 2012: 513). Weber, "siyasal topluluk" teriminin, bir "bölgeyi" içinde yaşayanların davranışını değiştirmeyi silahlı gücü içerecek şekilde fiziksel güce başvurmaya hazır olan ve kişileri sistemli bir egemenliğe tabi kılmaya hazır topluluklar için kullanılabileceğini dile getirmektedir. Yazar, bu anlamıyla siyasal grupların insanlığın tüm safhalarında ve her yerde bulunduğunu belirtmektedir. Fakat "siyasal topluluk 'yani bir toprak ve yerleşik halkın üzerindeki sistemli egemenliğin zorla devamının' bir ve aynı topluluğu işlevi olarak algılaması anlamında her yerde ve bütün zamanlarda var olmamıştır" (Weber, 2012: 267).

Asabiyet, aşiret gibi kavramlar bölgede yaşayan toplulukları tahlil etmek ve Muş bölgesi aşiret yapısını analiz etmek için de işlevsel kılınabilirler. Ancak Avrupa toplumlarını tahlil etmek için geliştirilen patrimonyalizm ${ }^{4}$ ve patriyarkalizm gibi kavramların, Muş sancağı ile diğer bölge aşiretlerini analiz ederken birebir örtüşmemesi de bir hakikattir. Ancak metnin içinde de görüleceği gibi bu kavramların bazı yönleriyle Muş bölgesindeki Kürt aşiretlerin durumunu ortaya koyan ampirik verileriyle ciddi tutarlılıkları bulunmaktadır. Dolayısıyla bu kavramların, bölge aşiretlerinin sosyo-ekonomik, sosyo-kültürel ve sosyo-politik yapılarını analiz ederken kullanmakta bir sakınca görülmemektedir.

Patriyarkalizm olarak kavramsallaştırılan yönetim anlayışında toplumlar ekonomik ve akrabalık temelinde bir grup/hane olarak örgütlenmeye giderler. $\mathrm{Bu}$ örgütlenme çerçevesinde topluluk belli kurallar içerisinde liderliği bir kişiye bırakmaktadır. Bu siyasal örgütlenme modelinde

4 Patrimonyalizm olarak kavramsallaştırılan olgu aşiretlerin, feodal el koymanın, geleneksel milis güçlerin çatışmalarda/savaşlarda temel rol oynadığı bir toplumsal düzeni içermekte; muktedirlerin gereksinimlerini karşılayan parayı kontrol ettikleri bölgelerden haraç ve kira şeklinde topladıkları dönemlere işaret etmektedir (Tilly, 2001: 63). egemenlik, efendinin doğuştan gelen bir hakkı olarak değerlendirilse de tüm üyelerin ortak çıkarları dikkate alınarak uygulanmak durumundadır ve dolayısıyla da muktedir tarafindan özgürce sahiplenilmemektedir. $\mathrm{Bu}$ sistemin sürekliliği ve korunması için de kişisel/patrimonyal bir kadronun mutlak yoğunluğu önemli bir koşul olarak öne çıkmaktadır. Bu yönetim anlayışında efendi, zor aygıtlarını kullanacak bir mekanizmadan yoksun olduğu için, ${ }^{5}$ grup üyelerinin rızasına dayalı gönüllü bir boyun eğmeyle iktidarını sürdürmektedir. Dolayısıyla üyeler, bu yönetim modelinde "kesin tabi" olarak değerlendirilmezler. Grup üyelikleri yasal bir yola değil, geleneklerle inşa edilmektedir. Aynı şekilde itaat de kanunlaşmış düzenlemeye değil, grup üyelerinin efendiye yönelik itaati şeklinde vücut bulmaktadır (Weber, 2012: 351). Patriyarkal egemenlikte grup üyelerinin kişiler üstü amaca bağlılığ́ veya soyut normlara boyun eğme gibi bir durum söz konusu değildir. $\mathrm{Bu}$ egemenlik anlayışında efendinin kendi hanesi üzerinde otoritesi kabul edilmektedir. Patriyarkal egemenlikte muktedirin meşruiyeti kişisel bağlılık yoluyla güvence alınmakta ve yalnızca kontrol gücünün niteliği ve sınırları "normlardan" kaynaklanmaktadır. Kanunlaştırılmayan bu gelenekler kutsallaştırılarak süreklilik kazandırılmaktadır (Weber, 2012: 371). Çalışmanın ileriki safhalarında görüleceği gibi, bu kısımda inşa edilmeye çalışılan kuramsal çerçevenin ampirik verileri Kürt toplumsal yapısında ziyadesiyle mevcuttur. Dolayısıyla sonraki bölümlerde arşiv belgeleri 1şı̆̆ında ortaya konulan ampirik verilerin, teorik çerçeve bağlamında okunmasında fayda mülahaza edilmektedir.

\section{Osmanlı Devleti’nin Kürt Mirleriyle İlişkileri}

Osmanlı Devleti, Kürt coğrafyasına ${ }^{6}$ doğru yöneldiği zamanlarda, 1500'lerde, bu coğrafyada bir dizi özerk emirlik yapısı bulunmaktadır. Bu yapıların bağımsızlık dereceleri, komşu imparatorlukların güçlerine bağlı olarak sürekli bir şekilde değişmiştir. Bazı görüşlere göre bu yerel iktidar sahiplerinin yapılanmaları örgütlenme ve sosyal tabakalaşma bakımında büyük devletlere benzemiştir. Osmanlı, bölgeyi topraklarına kattıktan sonra geleneksel Kürt mirliklerine dokunmamış, hatta onları güçlendirmiştir. $\mathrm{Bu}$ durum, 19. yüzyıldaki merkeziyetçi devlet uygulanmasına değin bu şekilde devam etmiştir. Fakat devlet bu dönemde de dolaylı yönetimi, tam olarak ortadan kaldırıp doğrudan yönetime geçmeyi başaramamıştır. Başka bir ifadeyle dolaylı yönetim düşük düzeyde de olsa devam etmiştir (Bruinessen, 2010: 297-298). Diğer yandan Osmanlı merkezi iktidarının desteğini arkalarına alan ve periferide yerel iktidar inşa eden Kürt mirleri Osmanlı sarayını kendilerine yön gösteren birer odak olarak değerlendirmiş, merkezi iktidar sahiplerini taklit etmekten geri durmamışlar (Bruinessen, 2010: 245). Osmanlı hakimiyetinde bulunan Kürt coğrafyasının yerel iktidarını inşa eden Kürt mirlikleri devlet olmamalarına rağmen

\footnotetext{
5 Patriyarkalizm anlayışını benimseyen devlet/toplumlarda efendinin kişisel yönetim kadrosu bulunmaz (Weber, 2012: 350).

${ }^{6}$ Sosyologlar; kültür ve medeniyetin ilk kaynağını, başka bir deyişle medeniyet ve kültürün ilk kaynağı olarak Dicle ile Fırat nehirleri arasındaki bölgeye yani Kürtlerin tarihsel olarak yaşadığı toprakları işaret etmektedir (Tenik, 2019 : 19).
} 
devlet olarak adlandırılan olgunun birçok niteliğine sahip olmuş, hatta kimi iddialara göre bazı devletlerden çok daha gelişmiş bir politik sisteme malik olmayı başarmışlar (Bruinessen, 2010: 297-298).

Yavuz Sultan Selim'in iktidarında Osmanl1-Kürt ilişkileri başladığında, yirmiye yakın Kürt miri Safevilere karşı Osmanlı'nın yanında yer almış, Osmanlı padişahına bağlılıklarını bildirmişler (Bruinessen, 2010: 215). Osmanlı ordusu, 1514 yılında Diyarbekir kapılarına vardığında, şehrin Kürt halk kapıları sonuna kadar açmıştır. Osmanlıyla iyi ilişkiler geliştiren bölge mirleri, daha önce Safevilere kaptırdıkları kaleleri de geri almaya başlamışlar (Bruinessen, 2010: 297-298). Osmanlı, Kürt coğrafyasını topraklarına kattıktan sonra 1517 yılına kadar üç yeni eyalet oluşturmuştur. Bu eyaletler; Diyarbakır, Rakka ve Musul topraklarından oluşturulmuştur. İlk olarak idari siteme dahil edilen eyalet, Diyarbakır eyaleti olmuştur. Bu eyalette, Kürt hükümeti olarak adlandırılan yerel iktidar güçlerinin geleneksel özerk yapıların serbest bir şekilde idare edilmesine karışılmamıştır. Kürt coğrafyasının neredeyse tümünde olduğu gibi bu bölgede inşa edilen Kürt hükümetleri de "merkezi hazineye vergi vermek ya da sipahi ordusunda askeri hizmet görmek zorunda değildi; topraklarl da tımar veya zeamet haline getirilemiyordu". Bölgenin diğer kısımları ise yirmi sancak olarak idari örgütlenmeye dahil edilmiştir. $\mathrm{Bu}$ yapıların bazıları merkezden atanan sancakbeyleri tarafindan yönetilirken, bazıları da yurtluk-ocaklık olarak Ekrad beyliği (Kürt sancaği) adı altında geleneksel Kürt aristokrasisinin yönetimine bırakılmıştır (Bruinessen, 2010: 239-240). Fakat Kürt mirlerinin merkezi iktidara karşı bazı yükümlülükleri olmuştur. Bölgenin sancakbeyleri savaşlara katıldıklarında beylerbeyine itaat etmekte, sancaklarından sağladıkları yıllık gelirlerinin bir bölümünü merkezi hazineye aktarmaktadırlar. Ancak bu durum, her zaman aynı titizlikle uygulanmış değildir. Merkezi iktidarın güçlü olduğu ve Osmanlı ordusunun yakın bölgelerde bulunduğu vakitlerde itina gösterilen bu vazifeler, devletin zayıflaması ve ordunun uzaklaşmasıyla yerini isyana veya itaatsizliğe bırakmış görünmektedir (Bruinessen, 2010: 240-241). Esasında benzer bir ilişkinin Kürt aşiretleriyle İran arasında da tarihsel olarak inşa edildiğini, İran coğrafyasında hegemonya kuran merkezi iktidarların Kürt aşiret reislerini aracı kılarak bölgelerinin özerk yapılar olarak devam etmelerine olanak sağladıkları anlaşılmaktadır (Ateş, 2013: $35)$.

Osmanlı devleti modernleşme süreci ilerlettikçe ve II. Mahmut (1808-1839) merkezileşmeye dayalı bir yönetim anlayışı benimseyince, merkezi iktidar denetimini tüm imparatorlukta yaymak için girişimlere ${ }^{7}$ başlamıştır. $\mathrm{Bu}$ siyasadan Kürt mirlerine de pay düşmüş, mirlerin miras yoluyla sahip oldukları geleneksel ayrıcalıkları ellerinden alınmıştır. Esasında II. Mahmut tahta çıktığı zaman, Kürt mirleri özerk yapılarını daha da genişletmiş, bölgedeki güçlerini sağlamlaştırmışlardı. Aslında, bu durum sadece bu coğrafyada değil, Osmanlı'nın her tarafına sirayet etmiş, valiler bile merkezi dinlemez olmuştur. Örneğin Misır, Mehmet Ali Paşa tarafindan "de facto" bir bağımsızlıkla

\footnotetext{
${ }^{7}$ Osmanlı sultanının modernleşme girişimlerinin başında 1926 yılında Yeniçeri Ocağı'nı kaldırmak olmuştur (bkz. Alt1, 2019: 52).
}

yönetilmiştir. $\mathrm{Bu}$ dönemde Erzurum ve çevresi Rusların kontrolüne geçmiş, devletin Kürt bölgesi üzerindeki etkisi iyi azalmıştır. $\mathrm{Bu}$ durumdan yararlanan Yunan milliyetçileri, bağımsız Yunanistan devletini kurmayı başarmışlar. Ancak tahtına iyice yerleşip muktedir olduktan sonra merkeziyetçi siyasını uygulamaya koymaya başlayan II. Mahmut, diğer bölgelerde olduğu gibi Kürt bölgesinde de yerel iktidar odakları üzerinde tahakküm kurmayı, tam manasıyla olmasa da, başarmıştır (Bruinessen, 2010: 268270).

Tarihsel olarak daha çok büyük devletlerin periferilerinde yaşamak durumunda kalan Kürt aşiretleri, uzamsal olarak uzak da kaldıkları merkezi iktidarlardan belli bir ölçüde siyasal özerkliğe sahip olmayı başarmışlar. Merkezi iktidar ile Kürt çevresi arasındaki ilişki biçimini çoğunlukla merkezi iktidarın sahip olduğu güç belirlemiştir. Sarkaç biçiminde bir ilişkinin geliştiği bu zeminde, toplumsal hareketlilik ziyadesiyle fazla olmuştur. Merkezi iktidarın güçlü olduğu zamanlarda devlete bağlılıkları kavileşen Kürt aşiret liderleri, devletin zayıfladığı devirlerde bağımsızlıklarını düşünecek kadar özerk bir ilişki biçimini geliştirmiş̧ler (Bruinessen, 2010: 203). Başka bir ifadeyle, Osmanlı merkezi iktidarıyla yerel Kürt iktidarı arasındaki ilişki, kimi zaman diyalektik (çatışmaya dayalı/çelişkili) bir hal alırken kimi zaman da dikotomik (ikili) bir durum arz etmiştir. $\mathrm{Bu}$ ilişkiyi etkileyen en önemli sebepler ise karşılıklı menfaat ve çıkarlar olmuştur. Osmanlı merkezi iktidarının belirleyici olduğu bu ilişski biçiminde, ikililik her zaman olmuş ancak bazen dayanışmaya bazen de çatışmaya dayanmıştır.

\section{Muş Sancağında Sosyo-Politik Yapının İnşası}

Osmanlı, Kürt bölgelerini topraklarına kattığı zaman, özerk bir yap1 inşa etmiş olan Kürt mirliklerinin bu niteliklerini sürdürmesine izin vermiştir. $\mathrm{Bu}$ mirliklerlerden bir olan Bitlis Kürt hükümeti, Şerefhanlar tarafindan idare edilmekte ve Bitlis, Ahlat, Hınıs ve Muş sancaklarını kapsamaktadır (Şeref Han, 1975: 485). Demografik ve sosyo-ekonomik yapısının çeşitliliğiyle öne çıkan Muş bölgesinin yönetimi, yurtluk-ocaklık olarak Bılbasi aşiret reisi Alaaddin Paşa'ya bırakılmıştır. Osmanlı'nın diğer bazı periferilerinde olduğu gibi Muş bölgesi de yurtluk-ocaklık şeklinde miras olarak babadan oğula geçecek biçimde bu aile bireylerine bırakılmıştır (Koç, 2018: 2). Muş’un yönetimsel statüsü, 16. yüzyıldan 19. yüzyıla gelinceye kadar bazı değişimlere uğramıştır. Şehrin 19. yüzyıldaki yerel iktidarı konumunda bulunan Alaaddin Paşaların 18. yüzyıldan önceki tarihleri tam olarak bilinmemektedir. Muş sancağının mütesellimi olarak Bitlis hükümeti tarafindan atanan Alaaddin Bey kimi ayrıcalıklara sahip olmuş, Bitlis hükümetinin desteğini arakasında hissetmiştir (BOA. C. DH. 270/13478, 13 Cemaziyelahir 1160 (22 Temmuz 1747 ; Koç, 2018: 39).

Muş sancağı kimi zaman Erzurum'a kimi zamanda Bitlis vilayetine bağlanmıştır. 1872 yılına gelindiğinde Erzurum Vilayetine bağl1 bir sancak durumunda olan Muş; Bitlis, Bulanık, Malazgirt, Çukur ve Kusur kazalarını havidir. 1892 yılında ise Muş; Merkez, Varto, Bulanık, Malazgirt ve Sason kazalarından müteşekkil bir sancaktır. 93 Harbi'nden (1877-78 Osmanlı-Rus Savaşı) sonra Bitlis vilayet olarak idari sitemi dahil edilince Muş, Bitlis vilayetine bağlı bir sancak haline gelmiştir (Tombul, 2019: 4). 19. yüzyılda 
Bitlis vilayetinin dört sancağının en önemlisi olarak öne çıkan Muş, büyük tarım alanları, zengin kültürel çeşitliliğiyle bu önemini ortaya koymaktadır. Kürt coğrafyasının en önemli ovalarından birine sahip olan Muş, dağlar tarafindan çevrilmiş geniş ovalarıyla bölgenin öne çıkan kenti olarak değerlendirilmektedir. $\mathrm{Bu}$ verimli ve geniş ovalar, Fırat nehrini besleyen en önemli kaynaklardan biri olan Murat suyu ile dağlardan gelen diğer su kaynakları tarafindan beslenmektedir. Verimli topraklarından dolayı Muş ovası altın kaynağı olarak görülmektedir. Aynı şekilde Muş dağları da zengin meyve ağaçları ve otlaklarıyla öne çıkmaktadır. Nüfusunun heterojen yapısı, Rusya ${ }^{8}$ gibi bir devletin sınırlarına yakın olması, Erzurum ile Van gibi önemli şehirlere coğrafi olarak yakın olması kentin önemini artıran diğer etkenler oluştur (Koç, 2018: 1-2).

1828'de Emin Bey'in kuzeni Abdurrahman Paşa, Muş mutasarrıfı iken Emin onun kethüdası olarak görev ifa etmektedir. Abdurrahman Paşa bilinmeyen sebeplerden dolayı, kuzenine görevinden el çektirmiştir. Ancak bundan kısa bir süre sonra Abdurahman Paşa, Bitlis'ten Muş'a giderken Emin ve kardeşleri tarafindan öldürülmüştür. Bu durumu sadarete bildiren Erzurum yöneticisi Galip Paşa, Muş sancağının mütesellimlik olması gerektiğinin de altını çizmeyi unutmamıştır. Galip Paşa, mütesellimlik görevi için de aynı aileden adaylar belirlemiştir. Bölgenin miras yoluyla geçen yurtluk-ocaklık olması bu durumu elzem kılmıştır (Koç, 2018: 48).

19. yüzyılda Muş ve çevresinin hakimiyeti için Emin Paşa (daha sonra Şerif Paşa) ile Hüseyin Paşa arasında baş gösteren mücadele bölgedeki güç yapısının değişmesine yol açmış, aşiret liderlerinin farklı pozisyonlar almalarına neden olmuştur. Bölgenin yöneticisi konumunda bulunan Şerif Paşa, Tanzimat döneminin ruhunu uygun uygulamalar için girişimlerde bulunduğu zaman Hüseyin Paşa onun tutum ve davranışlardan rahatsızlık duymuş, Şerif Paşa'nın daha önce ailesini terk eden aşiret ve kişilerden intikam almaya çalıştığını iddia etmiştir. Hüseyin Paşa, şerif Paşa tarafindan tehdit edilen ve yaklaşık olarak beş yüz aileye havi olan topluluk arasında Hizan Bey'i Şerafeddin, Huyut Bey’i Halil, Cibran Bey'i Süleyman Ağa ile Hesenan Bey’i Rıdvan Ağa'nın da bulunduğu ifade etmiştir. Hüseyin Paşa, Tanzimat'a göndermeler yaparak adalet talebinde bulunmuş ve Şerif Paşa'nın uygulamalarının Tanzimat'a aykırı olduğunu öne sürmüştür (Koç, 2018: 142).

Bedirhan Bey, Cizre bölgesinde isyan ettiği zaman Osmanlı'nın yanında yer alan Şerif Paşa ilk başlarda geleneksel yönetimsel pozisyonunu korumayı başarmıştır. Fakat, Bedirhan Bey'e karşı Osmanlı'nın yanında yer alan Şerif Bey, Nurullah Bey, Abdal Bey ve Yezdanşer gibi yerel iktidar sahipleri de zamanla tehdit olarak görülmeye başlanmış ve merkezi iktidarla karşı karşıya gelmek durumunda kalmışlar (Koç, 2018: 150). Kısacası Bedirhan Bey'in pasifize edilmesinden sonra devlet ile işbirliği yapan Şerif Bey gibi Kürt beyleri Bedirhan Bey ile aynı kaderi paylaşmış, yurtluk-ocaklık olarak atalarından kendilerine

\footnotetext{
8 1877-78 Savaşı'ndan sonra Rusya'nın Osmanlının elinden Kars Ardahan ve Batum'u alması Kürt topraklarını Rusya ile Osmanlı arasında bir sınır bölgesi haline getirmiş ve Rusya'nın Kürt coğrafyasına doğru ilerlemesi Rus-Kürt ilişkilerini doğrudan etkilemeye başlamıştır (bkz. Bajalan, 2019: 22).
}

intikal eden bölgeler ellerinden alınmıştır (Koç, 2018: 160). Bedirhan Bey ve Han Mahmud'un yerel iktidarlarının sonlandırılmasından sonra Osmanlı merkezi iktidarı, 1847 yılında Kürdistan Eyaleti adıyla Diyarbakır, Van, Muş, Hakkari, Cizre, Botan, ve Mardin bölgelerini kapsan yeni bir idari yapılanma inşa etmiş ve Kürt emirlik yapısını ortadan kaldırmıştır (Koç, 2018: 149).

Bölgenin önemli tarım arazilerine sahip ve heterojen bir topluma havi Muş sancağı, Osmanlı merkezi bütçesine de katkıda bulunmuş, Tanzimat'tan önce vergi olarak iki bin iki yüz kese yirmi sekiz (2228) kuruş ödemiştir. Fakat köylülerin farklı sebeplerden dolayı içine girdikleri sefaletten dolayı bölgeyi terk ettiklerini gören Esad Paşa'nın talebi doğrultusunda vergi miktarı 1845 yılında bin beş yüz keseye indirilmiştir. Tanzimat'tan sonra farklı yerlere dağılmış olan Muş halkı yeniden memleketlerine dönmeye başlamış, yarı-göçebe durumunda bulunan aşiretler de yerleşik hayata geçirilmiştir. $\mathrm{Bu}$ etkenlerle birlikte Muş'un vergisi 1849 yılında iki bin keseye yükseltilmiştir (Koç, 2018: 130). Bu bölümde de anlaşılacağ1 gibi Kürt bölgesinin diğer kısımlarında olduğu gibi Muş sancağında da patrimonyal bir anlayışla patriyarkal bir yönetim anlayışı geliştirilmiştir. Bir sonraki bölümde detaylı bir şekilde anlatılan aşiret ilişkileri, Kürt coğrafyasında patriyarkal bir düşünceyle aşiret üyelerinin reislerine gönüllü bir itaat sundukları, patrimonyal bir anlayışla yçnetimi resin ailesinin hakkı olarak değerlendirdikleri görülecektir.

\section{Kürt Așiretlerinin Gözüyle Așiretçilik}

Aşiret denilen fenomen temelde ortak ihtiyaçların karşılanması amacıyla bir araya gelmeye başlayan, kolektif bir bilinçle hareket eden grupların örgütlenme biçimlerinden biri olarak değerlendirilmektedir. $\mathrm{Bu}$ çerçevede bakıldığında Kürt toplumsal örgütlenmesi de genel itibariyle uzun tarihsel birikimlere dayanan örf ve adetlerin toplumsal ilişkinin şeklini belirlediği aşiret temelli yapıya dayanmaktadır (Altan, 2020: 16). Aslında Kürt toplumu da son beş yüzyıllık zaman diliminde toplumsal evrimin başlıca evreleri olarak değerlendirilen tüm aşamalardan geçmiştir: "Aşiret, reislik ve yart-devlet". Fakat Kürt halkı, bu evreleri normal akışında değil, geriye doğru yani tam tersi yönde yaşamıştır (Bruinessen, 2010: 300). $\mathrm{Bu}$ durumun yaşanmasında Kürt coğrafyasında Primordial (birincil, asli) bağlılıkların başında aileye, aşirete, aşiret ağasına veya reisine bağlılığın gelmiş olmasının ciddi bir etkisi olmuştur (Bruinessen, 2010: 19). Batılı araştırmacılara göre Kürt toplumunda aşiret denilen olgu, kendi üyelerini dış saldırılara karşı korumakla birlikte kendilerine ait gelenek ve yaşam biçimlerini sürdürmek amaciyla oluşmuş bir topluluk veya topluluklar konfederasyonu şeklinde yapılaşmıştır. Bu yazarlar, aşiret mensubu Kürtlerin, kendilerine sorulduğunda "eşiretim" ya $d a$ "ez eşir im" (ben bir aşiret mensubuyum) diye cevap verdiklerini, bu anlayışın farklı bir düzlemde de olsa Romalıların kendilerine "Civis romanus sum" (Roma vatandaşıyım) demelerine benzediğini öne sürmektedirler (Örs, 2019: 56). Ziya Gökalp de Kürtlerde aşiret mefkuresinin olan bu çok güçlü bağa dikkat çekmiştir (Gökalp, 1999: 46). Kürt toplumunda hakim toplumsal örüntü haline gelmiş olan aşiret mantığının tam da İbn Haldun dile getirdiği asabiyet düşüncesine ne kadar uyduğu görülmektedir. Kürt aşiretleri, birçok etkenden dolayı 
asabiyet kavramının içeriğinde olduğu gibi, aynı aşirete mensup aşiretdaşlarına yardıma koşmakta, onlar için ölümü göze almakta ve yeri geldiğinde başkalarının mallarına ve emlaklarına hep birlikte reisleri için el koymakta bir problem görmemektedirler.

\section{Muş ve Çevresinde Aşiretlerarası İlişkiler: Yerleșikler-Göçebeler, Çelișkiler-Çatıșmalar}

Muş bölgesinin mukim, büyük aşiretlerinden biri Hesenan aşiretidir. $\mathrm{Bu}$ aşiretin mensupları devlete bağlılıklarını bildirerek bölgede etkili olmayı başarmışlar. Ancak ağalarının tutuklanması aşiret mensuplarının tepkisine yol açmıştır. Yarı göçebe bir yaşam tarzı benimseyen bu aşiret, tamamen olmasa da 1870'lerde Malazgirt kazasının köylerinde geniş topraklar verilerek yerleşik hayata geçirilmiştir. Haydaran, Sıpkî ve Zilan gibi sınır aşiretlerinin Muş bölgesine gelişleri Muş beyleri tarafindan teşvik edilerek 19 . yüzyılın başlarında gerçekleşirken Hesenan aşiretinin Muş’a etkili bir şekilde gelişleri 19. yüzyılın ikinci yarısında gerçekleşebilmiştir (Koç, 2018: 264) İngiliz devlet yetkililerinden Mark Sykes 20. yüzyılın başlarında Hesenan aşiretinin 3,300 aileden oluştuğunu; Hınıs, Malazgirt ve Varto gibi bölgelerin 110 köyünde yaşadıklarını aktarmaktadır (Koç, 2018: 286) Kürt coğrafyasının diğer bölgelerinde olduğu gibi Muş bölgesinde de aşiretler arası çatışmalar hiçbir zaman eksik olmamıştır. Osmanlı arşiv kayıtlarına göre 1861 yılının yaz aylarında Van vilayetinde yaşayan Heyderan aşiretine mensup 30 atlı, Muş bölgesinde yaşayan ve yukarıda haklarında bilgi verilen Hesenan aşiretine ait bir kısrak, 3 at ve 15 sığırı gece karanlığından faydalanarak çalmışlar. Hesenan aşiret mensupları, hırsızları takip etmiş, malların bir kısmını geri almayı başarmışlar. Ancak hikaye burada sona ermemiş, Heyderanlar Muş Ahlat'ta yaşayan Hesenanların köyü Devlik'e saldırmış, iki aşiret arasında meydana gelen çatışmada, her iki taraftan olmak üzere, birçok kişi ölmüş ve yaralanmıştır (Koç, 2018: 300). Diğer taraftan Diyarbakır'ın göçebe aşiretleri olan Reşkotan, Pençnar ve Bekiran aşiretleriyle Siirt'in Siluki aşiretleri de 19. yüzyılın ikinci yarısında Muş bölgesinin yaylalarına gelmeye başlamış ve bölgede birçok sorunun yaşanmasına neden olmuşlar (Koç, 2018: 264).

Muş sancağı, bölgenin aşiretlerine ev sahipliği yaptığı gibi yaz aylarında Diyarbakır, Siirt ve Mardin gibi bölgelerden gelen Kürt aşiretlerine de mesken olmuştur. Bu aşiretlerden biri olan Alikan aşireti de Fettah Bey'in mahiyetinde yaz aylarını Muş’un yaylarında geçirmektedir. Osmanlı merkezi iktidarına itaat edip, boyun eğmeyen Hacı Fettah Bey, aşiretine sırtını dayayarak kış aylarını Siirt' in Garzan ve Rıdvan kazaları sınırlarında geçirirken, göçebeliklerinin bir gereği olarak yazları Muş sancağındaki yaylaklarına gelmektedir. $\mathrm{Bu}$ aşiret Muş’a gelirken yol üstündeki köylerle birlikte yolcuları talan etmekte, Muş bölgesi halkına karşı zulüm ile muamele etmekte, mal ve mülklerine el koymaktadır. Hem Siirt bölgesinde hem de Muş bölgesinde gerçekleştirdikleri tüm fenalıklar karşılıksız kaldığından, bu aşiret ve yol arkadaşlığı yaptıkları, güç birliği içinde bulundukları Pencinar ve Reşkotan aşiretleri ile Ömer Pertev Bey daha da büyük fenalıklara imza atmışlar. $\mathrm{Bu}$ aşiretler ve reisleri bölge halkına karşı pratize ettikleri zulümlerin yanlarına kalmasını firsat bilmiş gün be gün zulmün derecesini artırmışlar. Bu reislerden Hacı Fettah Bey'in “dört yüz haneyi şamil ve sekiz dokuz yüz silah-endaz zükur (erkekler) nüfusu cami' bir aşiret sahibi bulunduğu" "emr ü iradesine müsteniden şimdiye kadar bir nefer asker verdirmemiş ve tekalif-i saireden (diğer vergiler) dahi cüz'i bir şey" vermediği de anlaşılmaktadır (BOA, YEE, 78/36. 14 Teşrini Sani 95 (26 Kasım 1879). Muş bölgesine yaylağa gelen Ömer Purtev Ağa riyasetinde, dört yüz haneyi bulan nüfusuyla Alikan aşireti, göçebe bir aşirettir ve gelişgidişleri sırasında hem yolculara hem de bölge halkına karşı şiddet olaylarına karışmakta, cinayetler işleyip mallara el koymaktan geri durmamaktadır. Bir keresinde "Van vilayet$i$ celilesi muzafatından Bitlis kasabast hanedanindan Davsul Ăga'nın kasaba içinde vaki konă̆ı üzerine Ömer Burtev Ă̆a aşireti halkıyla maan (birlikte) hücum edip muharebe ve mukâteleye ibtidar ve bir gece ta-be (-e kadar) sabah imtidad (devam eden) eden muharebe-i hunrîzânede (kan dökücü) kendi tarafindan on nüfusu mütecaviz telefat verdikden sonra ă̆a-yı mümaileyhin konağını zabt ve üç dört adamını katl ve bilcümle mâmelekini nehb ü garat etmiş olduğu" raporlarda kayda geçmiştir (BOA, YEE, 78/33, 14 Teşrin-i Sani 95 (26 Kasım 1879).

Bölgenin genel durumu ortaya koyan birçok örneği Osmanlı arşiv belgelerinde bulmak mümkün. Muş, Erzurum Van, Siirt gibi bölgelerin aşiretlerinin geçiş noktasında bulunan bazı aşiretler ise yollardan gelip-geçen halkı soymakta, mallarına el koymakta bazen de canlarını rahatlıkla alabilmektedir. Özellikle bölgenin zengin tuz kaynaklarına sahip bölgelerine tuz almaya giden kervanların önünü keserek geçimlerini sağlayan aşiret ve aşiret reisleri de bulunmaktadır: Şirvan Kazasının Kefre köyünde mukim Mehmed ve Derviş Beyler gibi. $\mathrm{Bu}$ kişiler bölgenin Müslüman ahalisine saldırdıkları gibi Hıristiyan halkına da saldırmış, onlara zulmetmekten geri durmamışlar. $\mathrm{Bu}$ saldırıların şiddeti artınca bölge halkı bazen köylerini terk etmek durumunda kalmışlar. $\mathrm{Bu}$ durumdan faydalanan bölge aşiret reisleri, bu köylülerin mal ve emlaklarına al koymuşlar. Bu beylerden biri olan ve Muş, Van ve Erzurum yolunun kesiştiği alanlarda yol keserek tüccarların mallarına ve kimi zamanda hayatlarına kasteden Halil Bey oğlu İsmail Bey, bölgede yaşayanlardan birinin "zevce-i menkuhasını kaçırıp üç sene mütemadiyen nezdinde alıkoy(muş)" türlü fenalıklar yapmaktan geri durmamıştır. Aynı kişi Hiristiyan Hıdo'nun kardeşini zalimane bir şekilde katletmiştir. Bu sosyolojinin diğer yüzleri de bunlarla karşılaşınca meyanlarında çatışmalar çıkmış birçok insan öldürülmüş ve yaralanmıştır (BOA, YEE, 78/52-53. 14 Teşrin-i Sani 95 (26 Kasım 1879). Başka bir olayda, Muş’un Bulanık (Kop) kazasında aralarında bir jandarma subayının da bulunduğu çok sayıda kişi bölgenin Kürt aşiretleri tarafindan soyulmuş, Avrupa'dan gelen ve ticari eşya taşıyan iki nakliye arabasında bulunan tüm mallara arabalarla birlikte el koyulmuştur. Fransız konsolosun aktardıklarına göre, dönemin anayolu görevini gören bir yolun güvenliğinin sağlanması bile artık mümkün olamamaktadır. $\mathrm{Bu}$ da bölgenin sosyo-ekonomik ve sosyo-politik durumunu gözler önüne sermektedir (Erzurum Fransa Konsolos Yardımcısı'ndan Fransa Dışişleri Bakanı Delcasse'ye, no. 74/1, 13 Temmuz 1901, (MAE/AD Paris, Turquie, Erzurum, Seri B). Bu çerçevede bir durum değerlendirilmesi yapıldığında; Muş halkı bir taraftan bölgenin üst düzey yöneticileri olan kaymakam, tefeciler, vergi toplayıcıları ve yerel meclis üyelerinin kurduğu koalisyon tarafindan yüksek vergilerle, borçlarla sömürülürken diğer taraftan 
özelikle köylüler yarı göçebe ve göçebe aşiretler tarafindan saldırılara maruz kalmış ve bu gruplar tarafindan sömürülmüşler (Koç, 2018: 259). Kısacası Haldun'un içeriğini doldurduğu gibi asabiyet duygusunun güçlü olduğu yerlerde yaşananlar bu bölgede de yaşanmakta, aşiretler güçlünün haklı olduğu bir dünya inşa etmekte ve reisler bu zeminde kendileri için bulunmaz bir sosyo-politik yapı inşa etmektedirler. Aslında Weber' in de dile getirdiği gibi, aşiretler, kabileler ve etnik yapılar daha çok politik yapılanmalardır ve çıkar üzerine bina edilmişlerdir, kan bağıyla değil. Bu coğrafyada da benzer bir inşa söz konusu oldu, aşiretlerin çıkarları gereği bir araya gelip, yıllar sonra aynı adla adlandırıldıkları anlaşılmaktadır. Birlikte eşkıyalık yapıp farklı bölgelerden gelenlerin belli bir süre sonra aynı aşirete mensup olduklarını iddia ettikleri de görülmektedir.

Muş, Erzurum, Van, Bitlis ve Hakkari bölgelerinin yol güzergahlarını kesip aşiretiyle birlikte yoldan geçen tüccarların mallarına el koyan, onları kimi zaman canlarından eden bölge halkına her türlü zulmü reva gören aşiret reislerinden biri de Kerim Bey'dir. Fettah bey ile hareket eden Kerim Bey, devletin yürütme gücünü almayı başarmış, yol güzergahını fiili olarak kontrolüne altır. Yanlarına bölgede cesaretleriyle bilinen kişileri alan bu aşiret reisleri, yoldan geçenleri soymakla kalmamış, yolculardan bazılarını da katletmişler. $\mathrm{Bu}$ deni fiiliyatlarına rağmen çok az kişi onları şikayet etmeye cesaret edebilmiştir. Bu kişiler, bölgede aynı zamanda halkın mal ve mülklerine de göz dikmiş, firsat bulduklarında bunlara el koymayı unutmamışlar. Rakip aşiretlerle çatışmalara da giren bu zatlar, birçok insanın ölümüne ve yaralanmasına da sebep olmuşlar. Bölgedeki namlı eşkıyaları da kontrollerine alan bu reisler, halkın evlerini dahi yakmış, insanların her türlü haklarına tecavüz etmişler. Yeri geldiğinde merkezi iktidarı tanımayan bu zevat, şikayetlerden bir şey çıkmayacağını bildikleri için daha pervasız hale gelmişler (BOA, YEE, 78/59, 14 Teşrin-i Sani 95 (26 Kasım 1879). Bölgede yaşananlara bir bütün olarak bakıldığında Tilly'nin geleneksel toplumlarla ilgili yaptı şu tespitin ne kadar isabetli olduğu anlaşılmaktadır: Geleneksel toplumlarda/devletlerde "imparator, kral, prens, dük, halife, sultan" vb. muktedirler, memleketlerindeki hayatı kalıcı olacak biçimde düzenleyen devlet başkanlarından ziyade "fatih, haraç toplayıcı ve rantiyeciler" olarak ön plana çıkmışlardır (Tilly, 2001: 79). Bölgede durumu özetleyen Tilly'nin yukarıdaki cümleleri olmuştur.

Muş bölgesinde sahip oldukları yaylaklara yaz aylarında gelen aşiretlerden olan Pencinar aşiretinin ağavatından olan Bekro Ağa, aşiretin reisi Çeto Ağa ve onun vasıtasıyla Garzanlı Hacı Fettah Bey'in mensubatındandır. Kış mevsimini Rıdvan Kazasında Pencinar aşiret mensuplarıyla birlikte geçiren Bekro ağa, yaz aylarında Muş’taki yaylalara gitmeyi tercih etmiştir. Çeto ağayla birlikte hareket eden Bekro ağa, bir keresinde iki yüz kadar silahlı adamıyla birlikte yolları kesmiş, gelip geçenlerin mallarına el koymuş, bazılarının da canına kastetmiştir (BOA, YEE, 78/62, 14 Teşrin-i Sani 95 (26 Kasım 1879). Bekro Ağa, kontrolü altında bulunan aşiret üyelerinin askerlik hizmeti yapmasına izin vermediği gibi açık bir biçimde eşkıyalık faaliyetlerinde bulunanları yanında tutmuş, onları devlete teslim etmemiş, bölge halkına karşı gerçekleştirdiği bazı olaylardan dolayı hakkında yapılan şikayetler üzerine harekete geçen hükümet askerleriyle çatışmış ve dağlara firar etmiştir. Ancak en nihayetinde yakalanmış ve tutuklanmıştır. Bu ağa, Muş bölgesinde birçok deni fiiliyatta de bulunmuş, birçok olaya karışmıştır (BOA, YEE, 78/63, 14 Teşrin-i Sani 95 (26 Kasım 1879). Osmanlı merkezi iktidarının görevlendirdiği yetkililerin hazırladıkları raporlar dikkate alındığında, Kürt coğrafyasında geleneksel toplum yapısında hakim örüntü olarak karşımıza çıkan aşiret yapısı, bölge sosyolojisini derinden etkilemiş, birçok sorunun ortaya çıkmasına yol açmıştır. Diğer rapor ve çalışmalardan da aktarıldığı gibi aşiret yapısı, yapının sahip olduğu hiyerarşi, bölge halkının sos-kültürel, sosyo-ekonomik ve sosyo-politik yapısını dönüştürmüş, halkın kötü şartlarda birçok problemle boğuşmasına neden olmuştur.

Muş bölgesinde sorun çıkaran, birçok olaya karışan diğer bir aşiret Pencinar Aşiret ve reisi Çeto Ağa'dır. Çeto beş yüz haneye havi Pencinar aşiretinin riyasetinde bulunmuştur. Muş bölgesine yaptığı seyahatler sırasında aşiretiyle birlikte bölge halkına zarar veren Çeto Ağa, Muş bölgesinin havalisini de ziyadesiyle rahatsız etmekten geri durmamıştır. Her türlü zorbalığa başvuran ağa, yollardan gelip-geçenlerden haraç toplamış, mallarına el koymuş olmasına rağmen mahkeme önüne bir türlü çıkarılamamıştır. "Muş havalisinde İranus ve Manük ve Piri ve Hacu nam mebusların arzlhallerinde merkum Çeto ăga aşireti halkından otuz kadar avenesiyle beraber müsellahan karyeleri üzerine hücum eyleyerek dört yüz yetmiş üç re's ă̆namlarını ahz u gasb etmiş olduğundan bahisle icra-yl icabl ifade ve iddia ve Siird muhakeme-i bidayet azasindan Yusuf efendinin Haleb'li Ilyas'ı garizeye vekaleten muhakeme-i mezkurede vermiş olduğu istintaknamesinde (yazılı ifade) merkum Çeto ăga ile birader ve aveneleri tarafindan müvekkilinin iki yüz on re's ağnamı ve doksan beş aded lira-yl Osmanlu altunuyla eşya-yı sairesi Diyarbekr'le Siird arasında ki vaki tarik üzerinde gasb ettirildiği". Bu suçlara rağmen hiçbir zaman öahkeme karşısına çıkarılmayan Çeto ă̆a, ayrıca Van, Siirt ve Muş sancaklarinda ahali-i mazlume haklarinda zulm ve taaddiyatdan geri durmayı ettiği fenalıklardan dolayı tahtl cezaya aldırmamış ve yalnız Hacı Fettah beği kendisine ve ol bab da olan slyanet ve dalaletiyle aşireti halkına hakim tanıttırmış"tır (BOA, YEE, 78/36-38, 14 Teşrin-i Sani 95 (26 Kasım 1879).

Muş bölgesine gelip-giden aşiretlerden biri de iki yüz haneye sahip olan Bekran aşireti ve aşiretin reisi Keko-yı Hıssı Ağa'dır. aşiretiyle birlikte yaz aylarını Muş sancağında geçiren bu aşiret, 93 senesinde yaylaklarına giderken "sancă̆ın hükümet makarına (merkezine) bir buçuk saat bu'diyet mesafesi olan Menhum karyesi ahali-i gayr-i müslimesi üzerine kırk nefer avenesiyle hücum edib ahali-i merkumenin hanelerini yağma ve garat etmiş olduklarından sancak-ı mezkur mutasarrıflı̆̆ından zabtiye yüzbaşısı Kasım ăga refakatıyla bir kuvve-i kafiye merkum Keko Hissi A $\breve{g} a$ üzerine sevk ettirilib, teşhir-i silah ile mukavemete ibtidar ve imtidad eden muharebede beş nefer kendi tarafindan mecruh vuku' bulduğu gibi zabtiye neferâtından bir neferini katl ve bir neferide telef ettikden sonra meva-yl kadimleri olan Sason kazasına avdet edib”. Bekran aşireti ağası, yaylaklara çıkma yasağı olmasına rağmen, hükümet kararlarına uymayı reddetmiş, Muş sancağındaki yaylaklarına gitmeye devam etmiştir. Bekran aşiret mensupları ağalarının riyasetinde, meslek edindikleri işleri sürdürmüş, "meslek-i şekâvetkâranede aşâir-i saireye sebkat ve Van ve Bitlis ve Erzurum caddelerini sedd ile tarîk ve muvaredatın (gelen şeylerin) asayişini ihlal ve mücâsereti olduğu yalnız kattal 
maddeleri icmalen arz ve beyan ile kezalik tekalifin ekserisinden ve kura ve redif ve müstafaza gibi tekalif- $i$ askeriyeden müstesna bir hal ve tagallüb (zorbalı) ile yaşamakda bulunduğu tahkik kılınmış ve bu suret Siird meclis- $i$ idaresi tarafindan dahi ba mazbata tasdik kılınmışdır" (BOA, YEE, 78/61-62, 14 Teşrin-i Sani 95 (26 Kasım 1879). Garzanlı Reşid Bey’in oğlu Mehmed Ali Beg de aşiretiyle birlikte yol kesicilik yapmış, Muş sancağında sorunların yaşanmasına neden olmuştur. Bu ağa ve avanesi, "Muş sancă̆l ahalisinden Yusuf'un kayden tebeyyün eden arzıhal hülasası dahi bu merkum bir takım avane-i havanesiyle Diyarbakır caddesi üzerinde reh-i rastını kat' ve eşyâ ve melbusatını ve nukudunu ahz ve gasb etdikleri beyanından ibaret bulunmuşdur". Mehmed Ali Beg ve "şaki-i meşhurlardan merkumun hem amucazadesi ve hem kayın ve eniştesi bulunan Garzan'lı Başu Bey oğlu Genco Bey ile maan refakatlarında yirmiden mütecaviz Ekrad-l müselleha mevcud bulunduğu halde üzerine bi'l hücum altmış iki aded lira-yı Osmani altuniyla bir re's esb ve melbusatını ahz ve gasb ile götürmüş oldukları..." (BOA, YEE, 78/103, 14 Teşrin-i Sani 95 (26 Kasım 1879). Bu durumun Kürt coğrafyasının farklı bölgelerinde benzer bir şekilde yaşandığını farklı kaynaklardan teyit etmek mümkün. 19 yüzyılda bölgede bulunan batılı bir yetkilinin bu çerçevede aktardıkları şu şekildedir: "Hele bir de, eğer yanında bir kadın varsa, ne zaman bir atl görse korku içinde: "Aman Yarabbi! Bir haydut bu!". Zengenelerin haraç ve rüşveti Cafların her ne varsa elindeki Hemavand yolunda hemen hiç edilir" (Edmonds, 2003: 73).

Fransa'nın bölgedeki konsoloslarından biri de hazırladığı bir raporda bölge aşiretlerinin faaliyetlerini aktarmıştır. Fransız yetkiliye göre içinde Malazgirt'in de bulunduğu bazı bölgelerde ciddi çatışmalar yaşanmaktadır. Bölgenin Hıristiyan halkları ciddi sorunlarla karşılaşmaktadır. Raporda aktarılanlara bakılırsa; Hıristiyanlar can güvenliklerini sağlamak ve mallarını kurtarabilmek için Kürt ağa ve beylerin hesabına çalışmak durumunda kalmaktadırlar. Kürt ağa ve beylerin arasında neredeyse süreklilik arz edecek duruma gelmiş olan çatışmalarda da bu insanlar hayatlarından olmaktadır. Fransa konsolosu, bu olayların özellikle 1895 Ermeni olaylarından sonra meydana gelmeye başladığını ve bu durumun ortaya çıkmasında devlet yetkililerinin payının büyük olduğunu öne sürmektedir. Yetkilinin iddiasına göre bölgeye görevi çıkan yüksek devlet memurları, Kürt aşiret reislerini birbirlerini öldürmeleri için teşvik etmekte, yıllardır süren düşmanlıkları kaşımaktadırlar (Diyarbakır Fransa Konsolosluğu'ndan Fransa Dışişleri Bakanı Delcassé'ye, no. 76/1, Diyarbakır, 9 Ocak 1902, (MAE/AD Paris, Turquie, Diyarbakır, Seri B). Fransa'nın Erzurum konsolosunun hazırladığı başka bir rapora göre Muş ve Sason'da meydana gelen olaylarda, II. Abdülhamid tarafindan Kürtlerden teşkil edilen Hamidiye alaylarının rolünün altı çizilmektedir. Osmanlı olayları durdurmak ve bölgede sükûneti sağlamak üzere bazı üst düzey devlet yetkilisi göndermiştir. Bölgede çeteleşen kimi Kürt güçlerine karşı halkı korumak üzere düzenli ordu birliklerinin konuşlanacağı askeri kışla inşaatının yapılması için bölgede yaşayan halkı ikna etmek üzere gelen devlet yetkilileri Sason'a gitmişler. Fakat yöre halkı bu teklifi reddetmiş, askeri birliklerin bölgeye yerleşmelerini kendi menfaatlerine uygun bulmamışlar. Hamidiye'den sonra bir de askeri birliklerin bölgeyi daha da karmaşık bir duruma sokmasından korkmuşlar. Bunun üzerine devlet bölgeyi zorla kontrol altına almak için girişimlerde bulunmuştur. Fransiz yetki, devletin bu yeni tutumunun bölgedeki olayların artacağını yönelik endişeleri artırdığını iddia etmektedir. $\mathrm{Bu}$ olaylar üzerine Erzurum'un İngiliz Konsolosu Lamb'in da harekete geçtiği ve bölgeye ziyaretlerde bulunduğu anlaşılmaktadır. Ayrıca Van'ın Rus Konsolosu çıkan olaylardan dolayı Muş'a geldiği görülmektedir. Fransız yetkilinin iddiasına göre yaşanan olaylardan sonra yaklaşık 6000 Gregoryen Ermeni tarafindan imzalanmış bir dilekçe almıştır (Erzurum Fransa Konsolos Yardımcısı'ndan Fransa Dıșişleri Bakanı Delcasse'ye, no. 76/1, Erzurum, 24 Eylül 1901, (MAE/AD Paris, Turquie, Erzurum, Seri B). Bu minvalde Muş bölgesinde meydana gelen olaylardan biri de Musa Bey olayı olmuştur. Bu olay, Avrupa kamuoyunda da gündeme gelmiş, Avrupalılar yaşananlara sert tepki vermişler. Mutki Aşiretinin lideri konumunda bulunan ve devlet tarafindan kimi zaman nahiye müdürü olarak da görevlendirilmiş olan Musa Bey'in ilk vukuatı 1883'un Mayıs ayında Amerikan misyonerlere yapılan saldırı olmuştur. Aynı Musa Bey, daha sonra ise karşımıza bir Ermeni kaçırmasıyla çıkmaktadır. Darp ve tecavüz iddialarıyla anılan Musa Bey, aynı zamanda adam öldürme ve halkın mallarına zorla el koyma gibi suçlarla gündeme gelmiştir. Musa Bey, bu olaylardan takibata uğramış, hakkında birkaç dava da açılmıştır (Tombul, 2019: 5) Aşiretler bir yandan birbirleriyle çatışıp iktidar alanlarını genişletmeye çalışırken, diğer yandan Müslüman-Hıristiyan farkı gözetmeksizin her kesi aynı kefeye koymuş, benzer muamelelere tabi kılmışlar. Burada esas olarak öne çıkan, "ihtiyaç duydukları şey"in kendilerine verilip verilmemesi gibi görünmektedir.

Osmanlı'nın son demlerini yaşadığı dönemde Kafkas bölgesinden Muş bölgesine gelen göçmenler ile bölgenin yerli Müslüman halkı arasında da hâkimiyet mücadelesinden dolayı sorunlar yaşanmıştır. $\mathrm{Bu}$ sorunlar kimi zaman silahlı çatışmalara dönüşmüş ve bu çatışmalarda birçok insan öldürülmüştür. Bölge aşiretleriyle göçmenler arasında karşılıklı çatışmaların artması devleti harekete geçirmiş merkezi iktidar, olayların önlenmesi için güvenlik önlemleri almaya çalışmıştır. Ancak yine de sorunlar yaşanmaya devam etmiştir. 1893 yılına gelindiğinde Bulanık kazasının Simo Köyünde iskân edilen Osetler ile bölgenin büyük aşiretlerinden biri olan Sipkanlı (Sıpki) aşireti arasında çıkan olay ve onu takip eden çatışmada her iki taraftan yirmiden fazla insan öldürülmüştür (Öztürk, 2017: 108). Dikkat edilirse bölge sosyolojisi, din, dil, ırk fark etmeden, aynı sonucu vermektedir. Bölgenin yerleşik Kürt aşiretleri de, Hıristiyan halkı da, göçebe Kürt aşiretleri de dışarıdan gelen Kafkas göçmenleri de benzer tavır ve davranışlar sergilemektedirler. Çatışmalar, silahlı kavgalar bölgenin "normali" olarak görülmekte, bir yaşam biçimi olarak benimsenmektedir. $\mathrm{Bu}$ sosyolojide güçlü olanın efendi olduğu, iktidarı ellerine aldığı, zayıfın ezildiği hatta yok edildiği bir zemin oluşturmuş ve bunun üzerinde de kendisini yeniden üretmeyi başarmıştır. Her ne kadar İbn Haldun savaşın, insanlık tarihinde bulunan doğal bir durum olduğunu, savaş yapmamış hiçbir kavim ve toplum bulunmadığını (Haldun, 2016: 529). belirtse de, bölgede yaşananlar doğal olmanın ötesinde zamanın ruhunu yakalayamamış, zamanın gerekli düşünsel ve maddi 
aygıtlarından yoksun bir toplumun varlığını ortaya koymaktadır. Şiddeti bir yaşam biçimi olarak normalleştiren aşiret olgusu, toplumu derinden etkilemiş, bölge halkının modernleşmesinin önündeki en büyük engeli teşkil etmiştir. Modernleşemeyen ve onun gerekli araçlarına sahip olmayan bölge halkı zamanın gerisinde kalmakla yetinmemiş daha da geriye doğru yol almak durumunda kalmıştır/bırakılmıştır.

\section{Sonuç}

Osmanlı Devleti'nin genelde Kürt coğrafyasıyla özelde Muş bölgesiyle geliştirdiği ilişki biçiminin zamanın ihtiyaçlarına göre değiştiği anlaşılmaktadır. Kürt coğrafyasını sınırlarına dahil ettikten sonra "dolaylı yönetim” anlayışını benimseyen Osmanlı merkezi iktidarı, koşulların değişmesiyle bu siyasadan vazgeçmiş, "doğrudan yönetim” anlayışını uygulamaya çalışmıştır. Özerk Kürt mirlik yapısına uzun süre karışmayan hatta onu destekleyen, güçlendiren Osmanlı Devleti, modernleşmeye karar verdikten bu yapıları ortadan kaldırmaya, bölge halkıyla doğrudan ilişkiye geçmek için uğraşmıştır. Aracıları devreden çıkarak halka doğrudan ulaşıp, vergileri kendisi toplamaya çalışan merkezi iktidar, zaman içerisinde bu amacına ulaşmış, Kürt mirleri arasında var olan çelişkilerden yararlanarak, aralarında Muş bölgesini beyinin de olduğu aşiret reislerini tasfiye etmiştir. Koşulların belirleyiciliği altında gelişen Osmanl1-Kürt mirlerinin ilişkisi kimi zaman diyalektik (çatışmal1-çelişkili) bir hal alırken kimi zamanda dikotomik (ikili) bir hal almıştır. Merkezin güçlü olduğu devirlerde merkezi iktidarla iyi geçinen yerel Kürt iktidarı bölgede ikili yapı üzerinde inşa edilen geleneklere riayet edip kurallara uymuştur. Ancak merkezin zayıflamaya başlamasıyla Kürt mirleri uzamsal mesafeyi de firsat bilerek pozisyonunu değiştirmiş, çatışmayı göze almaktan geri durmamıştır.

Kürt aşiret yapısının hakim örüntü olduğu Muş bölgesinde mukim aşiretlerin içinde bulunduğu koşullar, Haldun ve Weber gibi sosyologların geliştirdiği kavram setleriyle, tahlil edildiğinde görülmektedir ki; çatışmalar ve çelişkiler bölge aşiretleri tarafindan bir yaşam biçimi olarak görülmüş, doğal bir durum olarak değerlendirilmiştir. $\mathrm{Bu}$ toplumsal zemin; vahşet, katliam, maddi varlıklara el koyma, devlete karşı koyma gibi çelişkilerin yaşandığı, felaketlerle sonuçlanan ilişkilerin yeşerdiği bir zemin olmuştur. Modern olanın yabancı olduğu bir coğrafyada, gelenekselin iliklere kadar hissedildiği bir toplumsal ilişki biçimi geliştirilmiştir. Etkileri halen hissedilen aşiretçilik mantığının egemen olduğu feodal zemin, bu coğrafyada birçok sorunun yaşanmasına sebep olduğu gibi, birçok şeyin ertelenmesine de yol açmış, bölgenin modern zamanın nimetleri olan eğitim, iletişim ve ulaşım araçları, gazete, kitap, sanayi gibi aygıtların bölgeye gelişini de geciktirmiştir. Kısacası geleneksel toplumların baskın formu olan aşiret yapılanması, Muş ve çevresinin sosyoekonomik, sosyo-kültürel ve sosyo politik yapısını derinden etkilemiş, bölge halkının zamanın ruhunu yakalamasını engellemiştir.

\section{Kaynakça}

Altan, B. (2020). Osmanlı Devleti'nin Son Döneminde Yap1, Sorunlar ve İngilizlerle İlişkiler Açısından Goyan Aşireti. History Studies, 12/1, 15-33.

Alt1, A. (2019). Balkanlarda Bektaşilik (XVII-XVIII. Yüzyıllar), Ankara: La Kitap Yayınları.

Ateş, S. (2013). The Ottoman-Iranian Borderlands Making A Boundary (1843-1914), New York: Cambridge University Press.

Bajalan, R. D. (2019). The First World War, The End of Ottoman Empire and the Question of Kurdish Statehood: A Missed Opportunity, Ethnopolitics, 18/1, 13-28.

Bruinessen, M. (2010). A $\breve{g} a$, Şeyh Devlet. İstanbul: İletişim Yayınları.

Charles; T. (2001). Zor, Sermaye ve Avrupa Devletlerinin Oluşumu. Ankara: İmge Kitapevi.

Edmonds, C. J. (2003). Kürtler, Türkler ve Araplar: KuzeyDoğu Irakta Siyaset, Seyahat ve Inceleme (19191925). İstanbul: Avesta Yayınlar1.

Ergut, F. (2015). Modern Devlet ve Polis. İstanbul: İletişim Yayınları.

Giddens, A. (2008). Ulus Devlet ve Şiddet. İstanbul: Kalkedon Yayınları.

Gökalp, Z. (1999). Kürt Aşiretleri Hakkın Sosyolojik Tetkikler. İstanbul: Toker Yayınları.

Hourani, A. (1990). Tribes and States in Islamic History. P. Khoury, J. Costiner (Ed.), Tribes and States in the Middle East içinde, University of California Press, Los Angeles.

İbn Haldun. (2016). Mukaddime, İstanbul: Dergah Yayınları, İstanbul.

Koç, G. (2018). Governing a Frontier Sancak in the Ottoman Empire: Notables, Tribes, and Peasants of Muş (1820s-1870s). (Yayımlanmamış Doktora Tezi). Boğaziçi Üniversitesi, Atatürk İlkeleri ve İnkalap Tarihi Enstitüsü, İstanbul.

Örs, O. (2019). Aşiretçilik, Milliyetçilik ve Íslamcılık Kavşağında Osmanlı'nın Kürt Siyaseti (1876-1909), İstanbul: Nubihar Yayınlar1.

Öztürk, A. (2017). Kafkasya'dan Muş Yöresine Göçler ve Iskan (1856-1905). (Yayınlanmamış Yüksek Lisans Tezi). Bitlis Eren Üniversitesi, Sosyal Bilimler Enstitüsü, Bitlis.

Şeref Han. (1975). Şerefname. İstanbul: Yöntem Yayınları.

Tenik, A. (2019). Tarihsel Süreçte Kürt Coğrafyasında Tasavvuf ve Tarikatlar, İstanbul: Nubihar Yayınları.

Tombul, S. (2019). Muş'ta Yaşanan Ermeni Olaylart (1885-1920., (Yayımlanmamış Yüksek Lisans Tezi). Kahramanmaraş Sütçü İmam Üniversitesi, Sosyal Bilimler Enstitüsü, Kahramanmaraş.

Weber, M. (2012). Ekonomi ve Toplum, Cilt I-II, İstanbul: Yarın Yayınları. 
Yılmaz, İ. (2014) Serseri Anarşist ve Fesadın Peşinde: II. Abdülhamid Dönemi Güvenlik Politikaları Ekseninde Mürur Tezkereleri, Pasaportlar ve Otel Kayıtları, İstanbul, Tarih Vakfi Yurt Yayınları.

\section{Arsiviler}

Türkiye Başbakanlık Osmanlı Arşivi

Fransa Dışişleri Bakanlığı Arşivi 